\title{
Transcendentality and Nothingness in Sartre's Atheistic Ontology
}

\author{
King-Ho LEUNG
}

\begin{abstract}
This article offers a reading of Sartre's phenomenological ontology in light of the premodern understanding of 'transcendentals' as universal properties and predicates of all determinate beings. Drawing on Sartre's transcendental account of nothingness in his early critique of Husserl as well as his discussion of 'determination as negation' in Being and Nothingness, this article argues that Sartre's universal predicate of 'the not' (le non) could be understood in a similar light to the medieval scholastic conception of transcendentals. But whereas the scholastics saw the transcendental properties of oneness, truth, and goodness as reflections of God's divine perfections, Sartre's predicate of the 'not' operates as an atheistic transcendental which signifies the nonbeing of God - that God is not. By comparing Sartre's phenomenological ontology to medieval theological metaphysics, this article not only highlights the atheist underpinnings of Sartre's entire ontological schema in Being and Nothingness but also offers a new way of interpreting Sartre as a systematic transcendental metaphysician.
\end{abstract}

\section{Introduction}

In her influential article 'Sartre and Negative Theology', Christina Howells (1981) highlighted some remarkable parallels between Jean-Paul Sartre's controversial account of 'nothingness' (néant) and the mystical conception of God. In light of Howell's insightful observation, recent scholarship has further explored Sartre's relation - and possible debt - to mystical theology (see Kirkpatrick, 2018; Pattison and Kirkpatrick, 2018, pp. 97-125; Kirkpatrick, 2017). ${ }^{1}$

Building on these fruitful engagements with Sartre, this article presents a comparison between Sartre's atheistic ontology and the Christian theological tradition. ${ }^{2}$ However, unlike recent 'mystical' readings of Sartre, this article offers a new interpretation of Sartre's account of

\footnotetext{
${ }^{1}$ See also Iris Murdoch's (1999) Existentialists and Mystics, whose title suggests an intuitive connection between Sartrean existentialism and religious mysticism.

${ }^{2}$ The focus of this article is on Sartre's earlier ('pre-Marxist') work on phenomenological ontology. On the religious and theological elements in Sartre's later (more political) works such as Saint Genet and Critique of Dialectical Reason, see King (1974, pp. 103-191).
} 
nothingness not in relation to the mystics but to the scholastics - especially the scholastic conception of the transcendentals. ${ }^{3}$

By comparing Sartre's 'transcendental' conception of nothingness to medieval accounts of transcendentality in scholastic theological metaphysics, this article puts forward a new interpretation of the notion of 'the not' (le non) which Sartre presents as a transcendental condition in his account of determination as negation in Being and Nothingness (hereafter cited as $B N) .{ }^{4}$ In particular, this article argues that Sartre's notion of nothingness plays a similar role in his atheistic ontology to that of the transcendentals in medieval theology: that Sartre's notion of nothingness operates as an atheistic account of transcendentality which signifies the absence or even death of God. ${ }^{5}$ To do so, this article firstly examines the notion of 'transcendentality' in relation to Sartre's early critique of Husserl, it then offers a reading of Sartre's account of 'the not' in his discussion of 'determination as negation' as well as his so-called 'ontological proof' in Being and Nothingness in comparison to the theological conception of transcendental properties in medieval scholastic metaphysics. Finally, the article concludes by showing how Sartre's avowed commitment to atheism underlies both his formulation of transcendental consciousness in terms of 'nothingness' and his universal predication of 'the not' as a transcendental property of all determinate being.

By way of treating Sartre's remarks on 'the not' as a universal predicate and his account of omnis determinatio est negatio as a speculative metaphysical thesis (following Spinoza and Hegel), ${ }^{6}$ this article seeks to shed new light on Sartre's ontological account of nothingness and negation which is often overlooked or ridiculed in the Anglo-American reception of Sartre (as

\footnotetext{
${ }^{3}$ Indeed, as Howells (1981, p. 550) points out: 'Throughout his writings, when discussing the notion of God, Sartre contrives to examine only the scholastic conception of Absolute Being.'

${ }^{4}$ Unless otherwise stated, quotations from $B N$ are taken Sarah Richmond's recent translation. References given below in the form, e.g., 'BN, p. 301/239/253', are first to Richmond's translation (Sartre, 2020), second to Hazel Barnes' earlier translation (Sartre, 2003), and third to the original French edition (Sartre, 1943).

${ }^{5}$ In 1943, the same year in which Being and Nothingness was released, Sartre published a review of Georges Bataille's Inner Experience which was Sartre's first publication that directly mentions 'the death of God'. See Sartre (2010a); see also Gillespie (2016, especially pp. 44-46).

${ }^{6}$ For a discussion of what Hegel and Spinoza respectively meant by this statement, see Stern (2016).
} 
notably found in A. J. Ayer's critique of Being and Nothingness, which will be briefly discussed below). ${ }^{7}$ By considering Sartre as a 'transcendental' philosopher not just in a (post-)Kantian idealist sense but in a pre-Kantian scholastic metaphysical guise,${ }^{8}$ this article seeks to contribute to the recent discussions of the question of 'God' in Sartre's works, ${ }^{9}$ as well as the reassessment of Sartre's relation to the tradition of transcendental philosophy and the history of metaphysics more broadly. ${ }^{10}$

\section{Reconsidering the transcendental}

Before considering Sartre's account of nothingness and 'the not' in Being and Nothingness, it is worth examining Sartre's earlier discussion of transcendentality in his critique of Husserlian phenomenology in his 1936 essay The Transcendence of the Ego, published seven years before Being and Nothingness. ${ }^{11}$ Contrary to Husserl's postulation of a transcendental I which unifies and personalises conscious experience, in this early essay Sartre (1972, p. 38) argues that 'phenomenology does not need to appeal to any such unifying and individualizing $I$ ' precisely because 'consciousness is defined by intentionality'. For Sartre (1972, p. 37), the very fact that the transcendental structure of consciousness is defined by intentionality means that there cannot be a 'transcendental $I$ ' or inner self that sits 'behind each consciousness [as] a necessary structure of consciousness'. Following Husserl's axiom that 'all consciousness is consciousness of something', Sartre (1972, p. 41) argues that transcendental consciousness is only consciousness by virtue of it being conscious of something which transcends

\footnotetext{
${ }^{7}$ See Gardner (2006, p. 248): 'The level in Sartre's philosophy that receives least attention - in English language commentary at any rate - is his ontology, his theory of being-in-itself, being-for-itself and nothingness.'

${ }^{8}$ On the connections between the scholastic and Kantian conceptions of transcendentality, see Honnefelder (2003).

${ }^{9}$ In addition to the aforementioned works, see also Chabot (2016); Gillespie (2013); Gillespie (2014).

${ }^{10}$ For some recent considerations of Sartre as a (post-Kantian) 'transcendental' philosopher, see Webber (2018); Morris (2016); Gardner (2011).

${ }^{11}$ For a full discussion of Sartre's critique of Husserl, see Webber (2020).
} 
consciousness itself: 'consciousness is not for itself its own object. Its object is by nature outside of it.'

Thus, if consciousness is conscious of an 'I' (e.g., when a conscious being consciously says ' $I$ think'), such an 'I' would by definition not be an ' $I$ ' that is transcendental. If a conscious being is conscious of an 'I', this 'I' would by definition be transcendent and not transcendental, it would be an object which transcends the consciousness of the conscious being - hence Sartre titles his essay The Transcendence of the Ego. For Sartre (1972, pp. 36, 41), transcendental consciousness is properly transcendental and conscious if and only if it is 'without an I': There is no room for an 'I' in consciousness. Anticipating his later characterisation of consciousness as 'a total void (since the entire world is outside it)' in Being and Nothingness (BN, p. 16/12/23; cf. $B N$, p. 9/7/17), Sartre writes in the conclusion of The Transcendence of the Ego:

The transcendental field, purified of all egological structure, recovers its primary transparency. In a sense, it is a nothing [un rien], since all physical, psycho-physical, and psychical objects, all truths, and all values are outside it... But this nothing is everything [ce rien est tout] because it is the consciousness of all these objects. (Sartre, 1972, p. 93, translation modified)

This characterisation of the transcendental as a universal structure applicable to 'everything' is one that very much echoes the pre-Kantian conception of transcendentals as universal properties of everything in medieval metaphysics: Indeed, as we shall further see below, there are remarkable parallels between Sartre's account of the 'not' (non) and nothing(ness) (néant) in Being and Nothingness and the pre-modern notion of transcendentality in the scholastic account of the divine names of the one, the true, and the good. ${ }^{12}$

\footnotetext{
${ }^{12}$ Cf. Sartre (2010a, p. 281): 'Bataille at times gives - and at times refuses - the name of God. It is a pure hypostatized nothingness [un pur néant hypostasié]... It is, in fact, one particular way of dissolving oneself into the nothing [le rien]. But that nothing is contrived in such a way that it becomes everything [Mais ce rien est habilement ménage de façon à être tout].' See also Gardner (2011, p. 61): 'The transcendental conception of consciousness is connected directly, therefore, with its specific ontological characterisation as nothingness: whatever is held to be transcendental cannot have anything of the character of an object - not even its being - and so, if it has existential status, must be "nothing(ness)".'
} 
While there are some differences in his later understanding of transcendental subjectivity, Sartre still conceives of transcendentality in terms of nothing(ness) in Being and Nothingness (BN, pp. 159-162/127-129/139-141, 325/259/264; see also Gardner, 2009, pp. 14-16, 90, 96, 99, 134-135). As its subtitle indicates, Being and Nothingness is not simply concerned with the transcendental structure of intentionality and consciousness: It is An Essay in Phenomenological Ontology that is concerned with both phenomenology and ontology with both consciousness and being. Being and Nothingness, as Jonathan Webber (2018, pp. 295-296) describes it, 'concerns the ontological structure of reality itself as well as the ontological structure of our consciousness of reality', a work in which Sartre 'turn[s] his philosophical attention from the structures of experience to the structures of reality itself ${ }^{13}$ As such, Being and Nothingness may be regarded as a speculative philosophical treatise which presents an account of the 'transcendental' not just in the Kantian sense of being the conditions for subjective cognition or conscious experience - what Sartre calls the "phenomenon of knowledge' (phénomène de connaissance), but also in the pre-Kantian sense of being the universal properties that can be predicated of all being - something very much similar to what Sartre calls 'the structure of being' (la structure de l'être) that is the focus of Being and Nothingness (see BN, p. 17/13/23). 'Sartre's claim in Being and Nothingness is, therefore,' as Sebastian Gardner (2011, p. 59) notes, 'that transcendental conditions must be construed ontologically.'

As opposed to Kant's 'modern' account of the transcendental in the first Critique which is 'occupied not so much with objects as with our mode of knowledge of objects', pre-modern scholastic metaphysics (what Kant called the 'transcendental philosophy of the ancients') conceived of 'transcendentals' as the essential properties of things themselves (Kant, 1929, p.

\footnotetext{
${ }^{13}$ See also Webber (2020, p. 162): 'in Being and Nothingness, the focus is on the being and structures of reality that do not depend on our experience of them... Sartre does not restrict the purview of his inquiry to the structures of experience.'
} 
59 [B25], emphasis added). As Kant notes in the first Critique, this 'older' transcendental philosophy is most famously expounded in the scholastic proposition 'quodlibet ens est unum, verum, bonum' - 'every being is one, true, good' (Kant, 1929, p. 118 [B113]). According to this medieval thesis, the terms of oneness, truth, and goodness are 'transcendentals' (transcendentalia), which are 'common notions' (communissima) that are universal properties of all things: They are called 'transcendentals' because they 'transcend' the Aristotelian categories in terms of their universal applicability. Insofar as 'every being is one, true, good', the notions of 'oneness', 'truth', and 'goodness' are said to be coextensive with 'being'. ${ }^{14}$

Unlike other predicates or adjectives such as 'happy', 'blue' or 'runny', each and every being can be predicated with 'one', 'true', and 'good'. While it would be odd to say that a chair is 'happy', that a handshake is 'blue', or that a sentence is 'runny', all of these things could be predicated with the scholastic transcendentals. Everything can be said to be one insofar as they are $a$ thing: every thing is one thing or indeed a unit with some level of unity or oneness (every chair is one chair, every handshake is one handshake, every sentence is one sentence). In a similar way, according to the scholastic medieval outlook, even if things are not fully or 'actually' good, everything has the potency to be good. Thus, everything can be predicated with 'goodness' ('that is a good chair', 'that is a good sentence', "there is a good handshake"). Likewise, all things can be said to be 'true' - or, so to speak, 'truthful' ('that is a true chair', 'a true sentence', 'a true handshake'): There is some level of truth in all things insofar as they ('truly') exist and are intelligible - that they contain some sense of 'truth'.

According to this scholastic outlook, insofar as oneness, truth and goodness are coextensive with being, there is a convertibility between these transcendental common terms. For instance, we can say that the true friend is also the good friend, and a good chair or a true

\footnotetext{
${ }^{14}$ This present account is obviously an extremely brief and simplified summary of a rich and complex tradition. For an in-depth and important study of the development of the medieval 'classical' conception of transcendentality, see Aertsen (2012).
} 
chair would be $a$ chair - one chair - that is whole and complete (as opposed to being incomplete, broken or indeed fragmented - not one). For the scholastics, this convertibility of the transcendentals is ultimately rooted and grounded in God: For God is supremely one, true, and good. God is the transcendent perfection and exemplary definition of oneness, truth, and goodness - the measure by which we measure the oneness, truth, and goodness of all created things: For scholastic thinkers such as Thomas Aquinas and his teacher Albert the Great, creatures and created things can be said to be one, true, or good only by virtue of their participation in God's divine perfections - the so-called 'divine names' - of Oneness, Truth, and Goodness (Aertsen, 2012, pp. 674-675; see also Aertsen, 1996). ${ }^{15}$

As opposed to this scholastic theological outlook which saw God's presence everywhere in the reflection of the transcendental properties of all things, Sartre was famously an avowed atheist, in his own words, someone with 'a phobia about God who saw his absence everywhere' (Sartre, 1967, p. 62). Indeed, in Being and Nothingness - Sartre's self-declared attempt to develop a 'truly atheist philosophy' - we can find something akin to a direct opposite of scholastic theology: Instead of reflecting the divine perfections of oneness, truth, and goodness, in Sartre's ontology all things signify the omni-absence of God (Beauvoir and Sartre, 1985, p. 436, see also pp. 437-438). As we shall see in the following sections, the traditional divine names of God as the one, the true, the good are replaced by nothingness in Sartre's atheistic ontological outlook: Whereas scholastic metaphysics saw God as the transcendent source of the oneness, truth, and goodness we find in the material world, 'nothingness' is defined as 'the origin and foundation' of the 'not' (non) which Sartre postulates as a universal predicate or even a universal condition of all determinate being. ${ }^{16}$

\footnotetext{
${ }^{15} \mathrm{Cf}$. Sartre's critical remarks on this 'theological' identification of Being, the True, and the Good in his essay on 'Cartesian Freedom' (Sartre, 2010b, pp. 513-516, especially p. 515).

${ }^{16}$ While Sartre's remarks that nothingness comes into the world through human consciousness in Being and Nothingness (e.g., BN, pp. 58-59/47-48/57) may seem to suggest that Sartre's a crypto-Kantian idealist who sees 'nothingness' merely as a product of human subjectivity, it is important to note that Sartre explicitly insists that consciousness itself belongs to 'being in general' (BN, p. 29/23/33). As further discussed below, Sartre defines
} 


\section{Determination as negation}

Alluding repeatedly to what Hegel (1969, p. 113) called the 'infinitely important' proposition of Spinoza 'omnis determinatio est negatio' ('all determination is negation'), in Being and Nothingness we find Sartre attributing a universal - or even 'transcendental' - predication of the 'not' or 'nothingness' to all things as determinate beings ( $B N$, pp. 48/38/49, 261262/208/221, 572/458/480; cf. Gardner, 2009, p. 63). As Sartre writes in his section on 'Determination as Negation' in Being and Nothingness:

Indeed, we should be quite clear that we can only refer to this being right here as 'this' against the ground of the presence of all being... the this is disclosed as a this by the 'withdrawal into the ground of the world' of all the other thises; its determination - which is the origin of all determination - is a negation. ( $B N$, pp. 256/203/216, 259/206/219)

What makes a being a determinate being - what makes it this rather than that or those - is negation. ${ }^{17}$ Insofar as every concrete particular thing is not the abstract totality of all things (what Sartre calls 'the ground of the world' here) and that all things are determinate or indeed determinable - that each thing is intelligible as a potential 'this' as opposed to an indeterminate 'undifferentiated ground of being' ( $B N$, p. 258/205/218), every thing can be predicated with the 'not': Every thing is not everything. ${ }^{18}$ Every thing that can be determined as a this rather

nothingness as 'a structure of reality' which manifests as 'an objective fact and not a thought' (BN, pp. 38/31/41, 40/33/43) - nothingness is not a product of human judgment but an intrinsic part of the structure of being itself. This point is further elaborated below.

${ }^{17}$ See Gardner (2009, p. 62): 'Sartre makes negation a transcendental condition of cognition: every concept and act of thought, Sartre argues, involves negation. Negation is presupposed in the application of any concept, either in individuating an object or in predicating something of it: to judge that $\mathrm{X}$ is $\mathrm{F}$ is to determine $\mathrm{X}$ as distinct from, i.e. not being the same as, Y, etc.' However, as further argued below, 'the not' is for Sartre not just a transcendental condition of cognition, but also a transcendental property of being itself. See note 33 below.

${ }^{18}$ Conversely, 'everything' can also be predicated with the 'not': Everything is not some particular thing. If 'everything' is, as Sartre submits (somewhat following Hegel), undifferentiated and indeterminate, then 'everything' is precisely not differentiated and not determinate. See BN, pp. 255-263/203-209/216-222, also pp. 44-50/36-40/46-51; cf. Sartre (1992, p. 483): 'All of Being is there but enmeshed in a total undifferentiatedness. So Being is at the same time not being' (Sartre's emphasis). 
than a that ('it is this and not that') - or indeed as a this rather than the whole world ('it is this and not everything') - can be universally predicated with a ' $n o t$ '. ${ }^{19}$

This predication of 'not' to things is precisely something we can find in the famous café scene in Being and Nothingness, where Sartre speaks of an 'intuitive discovery' of 'the not' (le non). ${ }^{20}$ To quote Sartre's observation of Pierre's absence from their scheduled appointment at some length:

When I enter the café to look for Pierre, a synthetic organization of all the objects in the café is formed, against which Pierre is given as having to appear. And this organization of the café as a ground is a first nihilation. Each element in the room - person, table, chair - tries to separate itself, to detach itself against the ground constituted by the totality of the other objects, and then collapses back into that undifferentiated ground... I am the witness of the successive dissolution of every object which I look at, especially the faces, which detain me for a moment ('Could that be Pierre?') and immediately disperse, precisely because they 'are not' [«ne sont pas»] Pierre's face... The 'not' [Le non], as a sudden intuitive discovery, appears as the consciousness (of being) conscious of the 'not' [conscience du non]. (BN, pp. 41-44/33-35/44-46)

The absence or 'not' of Pierre gives rise to the café observer's awareness of the 'are not' of the various elements in the café: the persons and their faces 'are not' Pierre, the table is not Pierre, the chair is not Pierre, and indeed the café itself is also not Pierre. ${ }^{21}$ For Sartre, Pierre's absence from the café is not a simple negation: It is not a subjective determination of a 'this' or 'that' but 'an objective fact and not a thought' (BN, p. 40/33/43). Pierre's absence in the café is one which brings to our attention not only the subjective fact that the various entities in the café are not Pierre (as perceived by the observing subject), but also the objective fact that all determinate beings can be predicated with the not (non) insofar as they are not the abstract indeterminate totality of all things. ${ }^{22}$

\footnotetext{
19 See also the comparison of Sartre's account of nothingness to Derrida's quasi-transcendental notion of différance in Howells (1988, pp. 194-201); cf. Toth (2007).

${ }^{20}$ For a compelling discussion of Sartre's café passage as a critique of Bergson and its philosophical significance, see Richmond (2007).

${ }^{21}$ As the entirety of the café 'remains as ground [which] continues to present itself to [the observer's] marginal attention as an undifferentiated totality' ( $B N$, p. 42/34/44).

${ }^{22}$ Pierre's absence is an instance of what Sartre calls négatités - 'nothings' or non-beings that have some concrete causal effects in the world $(B N$, p. 64/51/62). While Sartre's account of 'the objective existence of a non-being' $(B N$, p. 36/29/39) has received much criticism (especially) from analytic philosophers, recent works in analytic
} 
Inasmuch as Pierre's phenomenological non-being highlights the ontological condition of determination as negation, for Sartre it is nothing less than a manifestation of nothingness as 'a structure of reality, the origin and foundation of negation': Just as Pierre's non-being in the café is in some sense the 'origin' of the observer's awareness and attribution of the 'not' to various beings in the café, 'nothingness' is ontologically speaking 'the origin and foundation of negation' which enables consciousness to apprehend and experience things as determinate beings - as opposed to an undifferentiated ground of indeterminate being ( $B N$, p. 38/31/41). As Joseph Catalano (1985, p. 13) writes in his commentary on Being and Nothingness: 'Only nothingness, for Sartre, can be perfectly clear and perfectly reveal reality.'

To the extent that negation is understood 'not as one thing among other things but as the rubric of a category that governs the organisation and division of great masses of being into things', it may be said that for Sartre all determination - or even all 'meaning' - is predicated, conditioned and made possible by negation as a manifestation of nothingness (BN, p. 60/48/59, translation modified). Not unlike how transcendental perfections such as 'oneness', 'truth', and 'goodness' are not 'things among things' but overarching universal properties which structure all existent things in scholastic metaphysics, Sartre's 'nothingness' is a 'rubric of a category' which - transcendentally - 'governs the organisation' of all things: Just as all things may be predicated as 'one', 'true', or 'good' according to medieval scholasticism, for Sartre all

\footnotetext{
philosophy have defended the perceivability or even causal efficacy of absences or non-beings. See, for instance, Jago (2014, pp. 144-151). For Sartre, négatités are mind-related or even seemingly mind-dependent: They 'originate in a human being's act, or expectation, or project' and humans 'make continual use of négatités to isolate and determine the existents - in other words, to think them' ( $B N$, pp. 60/48/58, 64/51/62). However, négatités are also mind-independent 'transcendent realities' that are 'dispersed throughout being' which 'possess as much reality and efficacy as other beings' (BN, pp. 60/48/58, 57/45/56). As such, négatités are for Sartre 'conditions of reality' ( $B N$, p. 57/45/56) which signify the (negative) relation between the subjective mind and the objective world: 'all of them underline an essential relation of human-reality with the world... all of them underline an aspect of being as it appears to a human being engaged within the world' (BN, p. 60/48/58). The way in which négatités or non-beings reflect the negative relation between consciousness and being is further discussed in section four below.
} 
determinate beings can be predicated as ' $n o t$ ' insofar as they are not everything. ${ }^{23}$ But whereas the scholastic transcendentals refer and point back to God as the source of the oneness, truth, and goodness that is found in all being, Sartre's universal predicate of the 'not' is one which 'refers back to' (renvoyé) the 'nothingness, as a structure of reality, the original and foundation of [all] negation' $(B N$, p. $38 / 31 / 41){ }^{24}$

\section{The ontological proof of God's non-being}

The way in which nothingness constitutes 'a structure of reality' is closely related to the premises Sartre lays out in his 'ontological proof' presented in the introduction to Being and Nothingness: 'Consciousness is consciousness of something... consciousness arises oriented towards a being that it is not. Let us call this the ontological proof' (BN, p. 22/17/28, translation modified). Echoing his earlier argument against Husserl that the ego is not identical to transcendental consciousness as the ego is a transcendent being which we can be conscious of, in Being and Nothingness Sartre insists that insofar as a consciousness is conscious of some being, that being is by definition not the said consciousness (BN, p. 27/21/32).

As such, there is a negative ontological relation between consciousness (what Sartre calls the 'for-itself') and the thing which it is conscious of (the 'in-itself'):

What is present to me is not me... It is impossible to construct the notion of an object if there is not originally a negative relation by which the object is designated as that which is not consciousness... Before any comparison or any construction, a thing has to be present to consciousness as not being consciousness. The original relation of presence, as the foundation of knowledge, is negative... through the original negation, the for-itself constitutes itself as not being the thing. (BN, pp. 247-248/196-197/210, translation modified)

\footnotetext{
${ }^{23}$ Just as medieval 'transcendentals' are said to 'transcend' the Aristotelian categories in terms of their universality, Sartre's account of negation as a 'rubric of a category' (une rubrique catégorielle) may also be understood as a transcategorial notion which 'transcends' - or indeed 'preside over' - the level of 'category'.

${ }^{24}$ One may compare Sartre's notion of 'renvoyé' to Aquinas's 'return' (reditus) in his account of transcendental properties of creatures as reflections of God as their origin and end in De Veritate, XX.4: 'all things proceed from God into being, and... are ordained to God as to their end.... just as creatures would be imperfect if they proceeded from God and were not ordained to return to God, so, too, their procession from God would be imperfect unless the return [reditio] to God were equal to the procession' (Aquinas, 1994b, pp. 412-413).
} 
For Sartre, this 'original' negative relation between the in-itself and for-itself implies that the existence of some conscious being (the for-itself) logically entails that there is some existent being which it is conscious of - a transcendent being that is not consciousness (the in-itself) (see $B N$, pp. 20-23/16-18/26-29). Although it is debateable whether such a line of argument really constitutes an 'ontological proof' for the existence of the in-itself, one thing is clear: Sartre's 'ontological proof' is deliberately named as a subversion of the 'ontological' arguments for the existence of God as found in Anselm and Descartes (see BN, p. 7/6/16).

Indeed, Sartre's 'ontological proof' may be said to be nothing less than an atheistic argument against the existence of God (see Beauvoir and Sartre, 1985, p. 437; see also Gellman, 2009, p. 132; cf. Kirkpatrick, 2013, p. 162). As we have just seen, at the heart of Sartre's 'ontological proof' is the negative relation between the for-itself and the in-itself. ${ }^{25}$ The initself is by definition not the for-itself, the two ontological categories are strictly mutually exclusive: there cannot be a being that is both in-itself and for-itself - what Sartre calls an 'initself-for-itself, i.e. an in-itself that would be its own foundation in relation to itself' $(B N, \mathrm{p}$. 480/384/402). To quote a well-known passage from Being and Nothingness:

the in-itself-for-itself [is] the ideal of a consciousness that could be the foundation of its own being-in-itself purely by means of its own being conscious of itself. To this ideal, we can give the name 'God'. So we can say the best way to conceive of human-reality's fundamental project is to regard man as the being whose project is to be God. (BN, pp. 735/587/611-612)

The 'in-itself-for-itself' is regarded by Sartre as the 'ideal of the for-itself' because it is within the intentional character of consciousness for-itself to wish to fully grasp and comprehend the in-itself which it is not.

\footnotetext{
${ }^{25}$ See King (1974, p. 64): 'God is not possible for ontological reasons. The ontological reasons would be sort of a reverse form of St. Anselm's ontological argument. St. Anselm, by a logical analysis of the definition of God, wanted to show that God must exist by the very definition of what was meant by God. In Being and Nothingness the atheism of Sartre does the reverse: by a logical analysis of the definition of God - that is, by a consideration of the opposing properties [of the in-itself and for-itself] - Sartre mains that God is contradictory and therefore cannot exist.'
} 
However, human consciousness's wish to fully grasp and comprehend being in-itself and 'to metamorphose its own For-itself into an In-itself-for-itself' - to transform oneself into what Sartre calls 'God' - is inherently futile: Such a wish to become God is, in Sartre's famous words, 'a useless passion' (BN, p. 797/636/662). As we have seen, according to the original negative ontological relation on which Sartre bases his ontological proof, it is impossible to attain a complete unity or coincidence of the for-itself and in-itself: if the for-itself could fully grasps the in-itself, it would by definition no longer be for-itself - as there will no longer be a transcendent being in-itself for it be conscious of. Without anything to be conscious of, the foritself can no longer exist as consciousness. ${ }^{26}$

For Sartre, the for-itself's 'mission to make the in-itself-for-itself exist' - to 'become God' - is 'doomed, by definition, to failure' ( $B N$, p. 810/646/675). This is not just because the for-itself would cease to exist should it become in-itself-for-itself, but moreover because the very existence of God qua in-itself-for-itself is (onto)logically 'impossible':

[The in-itself-for-itself would be an absolute being] whose existence would be the unitary synthesis of the in-itself and of consciousness - this ideal being would be the in-itself as founded by the for-itself, and identical to the for-itself who founds it; in other words, it would be the ens causa sui... the indissoluble totality of in-itself and for-itself is conceivable only in the form of a being that is 'its own cause'... [But] this ens causa sui is impossible, and, as we saw, its concept contains a contradiction. (BN, p. 805/642/671)

Although the account of God as causa sui was one that was explicitly rejected in scholastic theology (for God is 'uncaused'), Sartre's formulation of God qua in-itself-for-itself as the 'unitary synthesis of the in-itself and consciousness' is nonetheless broadly in line with the traditional theological doctrine of divine simplicity. ${ }^{27}$

\footnotetext{
${ }^{26}$ For a detailed explication of this point, see Bantel (1979); cf. Wang (2009, pp. 267-273).

${ }^{27}$ Cf. Crittenden (2012, p. 499): 'Sartre would have derived the term ens causa sui as a name of God from Descartes' Meditations, for scholastic theologians, as Descartes acknowledged, all rejected the term. In the second of his five "ways", Aquinas observes that "We never find, nor ever could, that something is the efficient cause of itself, for this would mean it preceded itself, and this is not possible" [Summa Theologiae, I.2.3]... Duns Scotus and William of Ockham, critics of Aquinas on many issues, explicitly agreed with him in this regard.'
} 
According to this classical theological doctrine, God is his own being (esse): God's essence is simply his existence - what God is is that God is. ${ }^{28}$ One of the implications of the principle of divine simplicity - that God's essence and being are identical - is the scholastic teaching that God's act of understanding is identical with God's being: 'in God to be and to understand are one and the same' (Aquinas, Summa Theologiae, I.14.4, sed contra). To quote Thomas Aquinas:

Whatever is in God is the divine essence. God's act of understanding, therefore, is His essence, it is the divine being, God Himself. For God is His essence and His being... God's understanding [intelligere] is His being [esse]. (Summa Contra Gentiles, I.45, as translated in Aquinas, 1975, pp. 173-174)

In this theological outlook, in God we find a perfect identity of being and understanding - or as the theologian David Bentley Hart (2013, p. 235) puts it in phenomenological terminology, God 'is in himself the absolute unity of consciousness and being'. What this means metaphysically is that as finite creatures human beings only comprehend things insofar as they are drawn towards the perfect coincidence of being and understanding of God as the archè and telos of all being and consciousness (Hart, 2013, pp. 228-234, especially p. 231; cf. Aquinas, De Veritate, I.8).

Such a divine unity of being and consciousness - or what Sartre calls the in-itself and for-itself - is precisely an 'impossible and constantly indicated fusion of essence and existence' that 'haunts the for-itself' as it calls the for-itself to aspire to a state of being it could never attain (BN, pp. 273/217/230-231). Whereas scholastic theology believes that the noncoincidence of essence and existence in the finite immanent world points towards the

\footnotetext{
${ }^{28}$ See, for instance, Aquinas, Summa Contra Gentiles, I.21-22, and Summa Theologiae, I.3.4. Cf. Sartre's question in BN, p. 143/114/126: 'Is not God a being who is what he is' [un étre qui est ce qu'il est]?' Here Sartre further speaks of God as 'the necessary foundation of himself', also echoing the traditional theological principle of divine aseity - that God is 'of himself' (a se) because God is uncaused (and therefore cannot be causa sui). See Crittenden (2012, pp. 499-500): '[Scholastic metaphysics] referred to God as ens a se, meaning that God's being is absolute or unconditioned, a being existing "from itself" or "by itself" (by its own power). This was ordinarily taken in a negative sense to mean that God is not conditioned or caused by anything. But Descartes went beyond this to argue that the phrase $a$ se could also be understood in a positive sense... that "[God] is in a sense his own cause"... [through this] the term ens causa sui entered philosophy.'
} 
transcendent unity of essence and existence in God, for Sartre the disunity of essence and existence of things in the world signifies instead 'a missing God' (BN, p. 805/643/671), a 'constantly absent being which haunts the for-itself' ( $B N$, p. 142/114/126). As opposed to the in-itself-for-itself operating as an 'ideal fusion' of consciousness and being which we find in traditional theological metaphysics, what Sartre's ontological proof underscores and articulates is the intrinsic disconnection between the for-itself and in-itself which marks the 'universal absence' (absence universelle) of God (Sartre, 1988, p. 20). Instead of finding a reflection of God's oneness, truth, and goodness in the transcendental properties of all things, what Sartre presents in his ontology is an atheistic outlook in which the 'absence of God was to be read everywhere' (Beauvoir and Sartre, 1985, p. 435).

The universal absence or 'omni-absence' of God is precisely that which underlies Sartre's aforementioned attribution of the 'not' to all things. ${ }^{29}$ Although the medieval scholastics did consider the predicate 'not' (non) as a 'transcategorial' term insofar as the universality of its predication transcends the Aristotelian categories, the 'not' was emphatically not included among the transcendentals (Aertsen, 2012, p. 43). This is because whereas transcendental properties such as the one, the true, and the good always point towards some definite - and definitive - perfection, the predicate or the determination of the 'not' is indefinite. In other words, the 'not' (non) does not point to any concrete determinate qualities or properties - as Jan Aertsen (2012, pp. 29-30) notes in his important study of medieval transcendentality, 'indefinite names' (nomina infinita) or indeterminate predicates such as the 'not' (non) 'signify "nothing" (nihil) in the sense that do not signify any determinate matter, and "everything" (omnia), insofar as they are applicable to all matters'. ${ }^{30}$

\footnotetext{
${ }^{29}$ For Sartre, to 'say no' (dire non) to being (in-itself) may be regarded as an implicit rejection of God. See Sartre (2010b, p. 516): '[God] is the author responsible for everything in me that $i$. But by my finitude and limitedness, by my shadow side, I turn away from Him... To all these nothings, I can, as a nothing myself, say no [A tous ces nèant, néant moi-même, je puis dire non].'

${ }^{30}$ Here Aertsen cites Aquinas's teacher Albert the Great's commentary on Aristotle's Prior Analytic.
} 
In a sense, the medieval account of the 'not' as an indefinite name that does not name or signify any definite being is not dissimilar to a point made by A. J. Ayer in his early critique of Sartre's treatment of nothingness in Being and Nothingness. Echoing Carnap's famous criticism of Heidegger's assertion that 'Nothing nihilates itself', Ayer writes:

The point is that words like 'nothing' and 'nobody' are not used as the names of something insubstantial and mysterious; they are not used to name anything at all. What Sartre does, however, is to say that, being separated by Nothing, the objects are both united and divided. There is a thread between them; only, it is a very peculiar thread, both invisible and intangible. But this is a trick that should not deceive anyone. The confusion is then still further increased by the attempt to endow Nothing with an activity, the fruit of which is found in such statements as Heidegger's 'das Nichts nichtet' and Sartre's 'le Néant est néantisé'. For whatever may be the affective value of these statements, I cannot but think that they are literally nonsensical. (Ayers, 1945, pp. 18-19)

According to Ayer, Sartre treats 'nothing' as if it were an entity or some reified being. However, as Sarah Richmond (2013, p. 98) points out, such objections are anticipated by Sartre in Being and Nothingness when he insists that 'we cannot concede to nothingness the property of “nihilating itself'... only being can nihilate itself, because for something nihilate itself it is necessary, in some way or other, for it to be. [But] nothingness is not' (BN, p. 58/46/57).

Sartre's néant refers not to some reified being but to the gap or indeed the 'Nothing' that - as Ayer says - 'separates' the in-itself and for-itself (see BN, pp. 65/52/63, 128/102/114). As we saw earlier in Being and Nothingness, 'nothingness' must not be understood as 'one thing among other things' (BN, p. 60/48/59). Sartre's 'nothingness' refers not to a being but to a relation - to the ontological relation of not: that the for-itself is not the in-itself, a relation which only the for-itself (and not the in-itself) is aware or indeed conscious of. ${ }^{31}$ As such, in Sartre's ontological schema, the determinate predicate of 'not' may be said to function as a transcendental because it does signify something definite (and definitive) that is beyond the concrete phenomenal entities: namely, the non-coincidence of consciousness and being, the

\footnotetext{
${ }^{31}$ It is for this reason that Sartre says that the conscious human for-itself is 'the being through whom nothingness comes into the world', even though nothingness ultimately has its ontological origin in being in-itself. See note 16 above.
} 
original negative ontological relation between the in-itself and for-itself. ${ }^{32}$ Unlike the 'real' absence of Pierre or what Sartre calls the 'abstract' absence of the Duke of Wellington and Paul Valéry from the café, God's absolute absence is ontological and not just ontic ( $B N$, pp. 42-43/34-35/45). As opposed to the 'ontic' or 'relative' absences of Wellington, Valéry, or indeed Pierre, the absolute absence of God is not just the non-being or non-appearance of an (ontic) entity, but a definite and definitive ontological necessity (cf. Gardner, 2009, pp. 204205).

The necessary non-being of God (which marks the negative ontological relation between the in-itself and for-itself as well as the ontological impossibility of any absolute coincidence between being and consciousness) is for Sartre the ontological - or even transcendental - condition which enables consciousness to apprehend being: The for-itself can only be conscious of being because it does not coincide with - that it is not - being in-itself. ${ }^{33}$ As opposed to reflecting the perfect unity of being and intelligibility represented by God what Sartre calls the 'ideal fusion' of in-itself-for-itself, the 'not' (non) which Sartre attributes to all determinate being is one which signifies the nihil, the non-being of God which represents the absence and impossibility of any perfect coincidence between being and consciousness (cf. Beauvoir and Sartre, 1985, p. 442). The universal predicate of the 'not' signifies that God is

\footnotetext{
${ }^{32}$ Although Sartre clearly differs from Heidegger in insisting that Nothing cannot nihilate itself, Sartre's account of the original negative ontological relation could be seen as an (atheistic) appropriation of Heidegger's 'ontological difference' between Being and beings as the starting point of ontology. Cf. Heidegger (1998, p. 97): "The nothing is the "not" of beings, and is thus being, experienced from the perspective of beings. The ontological difference is the "not" between beings and Being. Yet just as Being, as the "not" in relation to beings, is by no means a nothing in the sense of a nihil negativum, so too the difference, as the "not" between beings and Being, is in no way merely the figment of a distinction made by our understanding.'

${ }^{33}$ Following Gardner's aforementioned suggestion that 'Sartre makes negation a transcendental condition of cognition' (note 17 above), it may be noted that this 'transcendental condition' of cognitive negation is reflective of - and indeed correlated to - the 'not' as an ontological relation. See Gardner (2005, p. 330): '[For Sartre,] the fulfilment of cognitive conditions is a necessary correlate of the ontological relation... a negative ontological relation.'
} 
not ${ }^{34}$ that it is not God but nothingness (nihil) that is the origin of all meaning and determination..$^{35}$

However, unlike the scholastics' God, Sartre's nothingness is not the uncaused cause and origin of all being and their transcendental properties. As we just saw, Sartre insists that nothingness cannot nihilate itself and only being can nihilate itself: nothingness can only come about through the nihilation of being. ${ }^{36}$ As such, for Sartre, nothingness has its origin in being and fundamentally derives its existence from being:

being is antecedent to nothingness and founds it... it is from being that nothingness derives its efficacy. We express this by saying that nothingness haunts being... the nothingness that is not can have only a borrowed existence: it takes its being from being. (BN, pp. 50/40/50-51)

Even though Sartre does not provide a reason or explanation for the emergence of nothingness in Being and Nothingness, ${ }^{37}$ from this passage we can see that it is within the capacities or even the character of being in-itself to nihilate or negate itself to bring into existence the for-itself, which in turn introduces nothingness into the world of determinate beings through negations: Although Sartre holds that nothingness arrives in the world through (par) consciousness, nothingness ultimately has a pre-subjective source in being itself..$^{38}$

\footnotetext{
${ }^{34}$ On the paradoxicality of this positive signification of an absence, see the analysis of Sartre's 'paradoxical logic of nothingness' in Toth (2007). See also the discussion of the paradoxical way in which 'God is present through his absence' throughout Sartre's atheistic philosophy in Gillespie $(2013 ; 2014)$.

${ }^{35}$ As such, Sartre's nothingness parallels the way in which God is posited as the source of truth and intelligibility in scholastic metaphysics. See Sartre's (1995, p. 20) remarks on the structure of truth in an essay written five years after Being and Nothingness: 'Non-Being intervenes directly as structure of truth... truth is a certain nonbeing of Being... Nothingness intervenes in truth.' See also note 40 below.

${ }^{36}$ Cf. Sartre (1992, pp. 150-151): 'Being-in-itself has to being about its own negation... Being already has a sort of existence at the extreme tip of Nothingness. It cannot come from Nothingness, therefore it must already be in some way in order to uphold Nothingness in its being. The result is that finally it is Being that upholds the Nothingness that must found it. So that it finally comes down to saying that Being is either beyond or on this side of Nothingness.' See also Sartre (1992, p. 520).

${ }^{37}$ Sartre notes that the question of 'why' the for-itself arises from being is a 'metaphysical' - as opposed to 'ontological' - problem, which lies beyond the 'ontological' concerns of Being and Nothingness as an essay on phenomenological ontology. See BN, pp. 800-803/639-640/667-669. See the fascinating analysis of Sartre's distinction between ontology and metaphysics in relation to his atheism and Schelling's so-called 'onto-theology' in Gardner (2006); cf. King (1974, p. 41).

${ }^{38}$ See Gardner (2011, p. 56): 'A metaphysical position which attributes the constitution of the objects of cognition to the structure of the subject, and which, like Kant, stops the story at that point, counts straightforwardly as a subjective idealism. But if the structures are traced back in turn to a pre-subjective source - such that, when the subject posits objects, its positing of objects derives ultimately, albeit indirectly, from being itself - then it is not so obvious that we have an idealism, or at any rate, that we have an idealism of Kant's subjective sort. And on
} 
As such, Sartre's notion of 'nothing(ness)' operates as a transcendental in the sense of being 'the structure of experience' (à la Kantian transcendentality) as well as 'the ontological structure of reality itself' (à la scholastic transcendentality). ${ }^{39}$ Nothingness is for Sartre not just a product or feature of human consciousness and cognition, but a mind-independent dimension of reality that is embedded in being itself - even if it is one that needs human consciousness (or what scholastics call the intellectus) to be 'noted or felt' (BN, p. 64/51/62; see also Gardner, 2011, p. 56). ${ }^{40}$ As a reflection of the negative ontological relation which underlies all being, the 'not' operates as a transcendental property that is found in each and every determinate being: "The necessary condition for the possibility of saying "not" is that non-being should be constantly present, within us and outside us, that nothingness should haunt being' ( $B N, \mathrm{p}$. 44/35/46). Just as being is 'haunted' by nothingness, the 'not' is for Sartre an atheistic transcendental which conditions, structures, and indeed 'haunts' all determinate being. Parallel to the way in which the transcendental properties of oneness, truth, and goodness refer to the perfect coincidence of being and consciousness which scholastic theology calls 'God', in Sartre's ontology we find the transcategorial predicate of the 'not' (non) playing the role of a transcendental which signifies the nihil - the nothingness which marks the 'universal absence' and non-being of God.

\section{Conclusion}

\footnotetext{
Sartre's full metaphysical account... this is exactly the picture - when the subject bestows structure on being-initself, yielding an intelligibly differentiated world of objects, it follows an imperative which derives in the last resort from being itself.'

${ }^{39}$ This point could be illustrated by Sartre's notion of négatités which function like Kant's 'regulative concepts' that enable us 'to isolate and determine existents - i.e., to think them', but are also 'conditions of reality' that are 'dispersed in being' (BN, pp. 56/45/57, 64/51/62). Cf. Webber (2018, pp. 295-296). See also note 22 above.

${ }^{40} \mathrm{Cf}$. Aquinas's remarks on the transcendental character of 'truth' in De Veritate, I.2, resp. and ad. 1 (Aquinas, 1994a, pp. 11-12): 'A thing is not called true, however, unless it confirms to an intellect. The true, therefore, is found secondarily in things and primarily in intellect... true is predicated primarily of a true intellect and secondarily of a thing confirmed will intellect. True taken in either sense, however, is interchangeable with being, but in different ways.'
} 
As mentioned above, Sartre remarks later in his life that his project in Being and Nothingness was an endeavour to develop a 'truly atheist philosophy' through which 'the absence of God was to be read everywhere' (Beauvoir and Sartre, 1985, pp. 435-436). This avowed atheism is something which underlies both Sartre's early critique of Husserl's transcendental phenomenology as well as his more developed ontological schema in Being and Nothingness. ${ }^{41}$ As we saw in section one's discussion of The Transcendence of the Ego, Sartre insists on the impossibility of the existence of any transcendental 'I'. As Gardner (2009, p. 15) points out, 'Sartre's expunging of Husserl's transcendental "I" is to establish a kind of atheism of consciousness'. Indeed, the atheistic elements of Sartre's rendition of a transcendental consciousness 'without an I' are notable when we consider Sartre's rejection of Husserl's transcendental ego in light of the definition of God as the impossible ideal unity of the foritself and in-itself - of the conscious knower and the being that is known - given in Being and Nothingness: If the ego could be transcendental consciousness (the for-itself) and simultaneously something that the said consciousness is conscious of (the in-itself), the 'transcendental ego' would therefore be a God-like unity of in-itself-for-itself, which for Sartre is strictly impossible (cf. King, 1974, pp. 69-71).

In addition to 'removing God from the cogito' through his phenomenological rendition of human consciousness for-itself as a transcendental nothing (Kirkpatrick, 2017, p. 129), ${ }^{42}$ as we further saw in the discussion of Being and Nothingness in sections two and three, Sartre's ontological attribution of the 'not' (non) to all determinate beings also functions an atheistic

\footnotetext{
${ }^{41}$ See Sartre (1962, p. 200): 'I did not consider myself to be any the less a metaphysician in refusing existence to God than Leibnitz was in granting it to Him.'

${ }^{42}$ See also Sartre (2010b, p. 515$)$ : '[T] he human being is nothing [un nèant]. It is by his nothingness, and inasmuch as he has dealings with Nothingness, Evil and Error that man escapes God, for God, who is infinite fullness of being, cannot either conceive or govern nothingness.' For Sartre, there is a latent atheist dimension to Descartes' cogito: 'I can bracket out all existents and I am exercising my freedom to the full when I, myself an empty nothingness, void everything that exists [je néantis tout ce qui existe]. Doubt is a breaking of contact with being... Being this pure negation, ... man isn't a "natural" being: But at the point when he achieves this unparalleled independence... against God, he catches himself being pure nothingness: over against the being that is entirely bracketed out, all that remains is a mere no... it is this translucent rejection of everything that is itself attained in the cogito' (Sartre, 2010b, pp. 516-518).
} 
structure of being that 'transcendentally' signifies the nothingness (nihil) which marks the omni-absence of God. Contrary to the theological outlook of medieval scholastic metaphysics, for Sartre, being is not one, true, or good, but instead intrinsically and irredeemably godless. By giving 'nothing(ness)' a transcendental status - in both the Kantian and pre-Kantian scholastic sense of transcendentality, what we find in Sartre's Being and Nothingness is not only a subversion of the traditional metaphysical conception of the transcendentals and divine names but moreover an ontological outlook in which the non-being of God is reflected in each and every determinate being. ${ }^{43}$

While it may be (rightly) argued that Sartre's postulation of the non-being and absence of God in his ontology is fundamental to securing the radical freedom of the conscious human being for-itself, Sartre's atheistic insistence on God's inexistence is not motivated solely by his (ethico-political) commitment to human freedom, but also (and perhaps more fundamentally) informed by his phenomenological and ontological account of the structures of conscious experience and the structures of being itself which derives from Husserl's axiom that 'all consciousness is conscious of something' ${ }^{44}$ As such, what we find in Sartre is not just an innovative unification of phenomenology and ontology, but also by extension a harmonisation of the Kantian subjective and pre-Kantian scholastic 'pre-subjective' accounts of transcendentality.

By considering Sartre's ontological schema in relation to the speculative theological metaphysics of pre-Kantian and indeed pre-modern scholastic philosophy, this article has offered a reading of Sartre's philosophical project as a bold and innovative endeavour in developing a 'systematic transcendental metaphysics' from 'a consistently atheistic position'

\footnotetext{
${ }^{43}$ Perhaps Sartre's (1988, p. 28) remarks on Mallarmé may also be applicable to Sartre himself: 'Whereas they had adored God's presence... [and] depicted a Universe glowing with Divine Light; he shall portray a world where this light is extinguished, a world in shadow... They had sung the praises of the intelligible world of Beauty, of absolute Truth... like them, he shall also speak about the Beautiful and the Ideal, but for him it is the Absolute which seems but a dream.'

${ }^{44}$ Cf. Kirkpatrick's $(2018$, pp. 4, 210) argument that Sartre's atheism is 'a theologically informed atheism'.
} 
(cf. Sartre, 1973, p. 56; Gardner, 2005, p. 327). Interpreting Sartre's work from this perspective can not only contribute some new insights to the contemporary discussions on ontology and metaphysics, ${ }^{45}$ seeing Sartre as a creative and avowedly atheist (re)interpreter of traditional metaphysical theses that had been broadly theistically construed (be it Anselm's and Descartes's ontological proof or Spinoza's and Hegel's omnis determinatio est negatio) can moreover shed some light on our understanding of the intricate boundary between philosophy and theology. ${ }^{46}$ As Sartre himself remarked, to live authentically as an atheist is a 'cruel' and difficult business: 'It's hard. Even those who think they have succeeded in becoming conscious, deliberate atheists are certainly still imbued with divine notions' (Sartre, 1967, p. 157). ${ }^{47}$ Whether one finds his ambitious attempt to construct a systematic - or even somewhat 'scholastic' - atheist metaphysics successful or not, perhaps one cannot help but be impressed by Sartre's bold and forceful effort to philosophically affirm that 'God does not exist' and indeed 'to draw the consequences of his absence right to the end' (Sartre, 1973, p. 33). ${ }^{48}$

\section{References}

Jan A. Aertsen, Medieval Philosophy and the Transcendentals: The Case of Thomas Aquinas (Leiden: Brill, 1996).

Jan A. Aertsen, Medieval Philosophy as Transcendental Thought: From Philip the Chancellor (ca. 1225) to Francisco Suárez (Leiden: Brill, 2012).

Thomas Aquinas, Summa Contra Gentiles, Book 1: God, trans. Anton C. Pegis (Notre Dame, IN: University of Notre Dame Press, 1975).

\footnotetext{
${ }^{45}$ For instance, bringing Sartre's account of nothingness into conversation with the scholastic - and especially Aquinas's - account of analogical prediction (e.g., between God's perfect Goodness and creatures' finite goodness) not only provides a new angle into the recent readings of Sartre as an ontological pluralist, but also resonates with the broader contemporary scholarship on ontological pluralism and the analogy of being in analytic philosophy which draws substantially from both scholastic and continental philosophy. See McDaniel (2017, especially pp. 5-8, 16-17, 42-44 on Aquinas; pp. 48-77 on the analogy of being more broadly; and pp. 140-169 on ontological pluralism and structures of 'absence' - in a chapter notably titled 'Being and Almost Nothingness'). On Sartre's 'ontological pluralism', see Erhard (2020, pp. 172-185).

${ }^{46}$ This has been the focus of many works in contemporary French phenomenology following its so-called 'theological turn'. (see Gschwandtner 2018; Janicaud et al., 2000).

${ }^{47}$ Cf. Beauvoir and Sartre (1985, p. 438): 'Even if one does not believe in God, there are elements of the idea of God that remain in us and that cause us to see the world with some divine aspects.'

${ }^{48}$ I would like to thank the two anonymous reviewers for Philosophy for their invaluable comments and insights. I would also like to thank Professor Judith Wolfe and the Templeton Religion Trust for their generous funding which made the research for this article possible.
} 
Thomas Aquinas, Truth: Volume I, Questions I-IX, trans. Robert W. Mulligan (Indianapolis, IN: Hackett, 1994a).

Thomas Aquinas, Truth: Volume II, Questions $X-X X$, trans. James V. McGlynn (Indianapolis, IN: Hackett, 1994b).

A. J. Ayer, 'Novelist-Philosophers V: Jean-Paul Sartre', Horizon 12 (1945), 12-26.

Robyn A. Bantel, 'The Haunting Image of the Absolute in the Work of Sartre', Research in Phenomenology 9 (1979), 182-197.

Simone de Beauvoir and Jean-Paul Sartre, 'Conversations with Jean-Paul Sartre, August-September 1974', in Simone de Beauvoir, Adieux: A Farewell to Sartre, trans. Patrick O’Brian (London: Penguin, 1985), 129-445.

Joseph S. Catalano, A Commentary on Jean-Paul Sartre's Being and Nothingness (Chicago: University of Chicago Press, 1985).

Alexis Chabot, 'Cruel Atheism', Sartre Studies International 22 (2016), 58-68.

Paul Crittenden, 'Sartre's Absent God', Sophia 51 (2012), 495-507.

Christopher Erhard, 'Negation, Nonbeing, and Nothingness', in Matthew C. Eshleman and Constance L. Mui (eds.), The Sartrean Mind (London: Routledge, 2020), 172-185.

Sebastian Gardner, 'Sartre, Intersubjectivity, and German Idealism', Journal of the History of Philosophy 43 (2005), 325-351.

Sebastian Gardner, 'Sartre, Schelling, and Onto-theology', Religious Studies 42 (2006), 241-271.

Sebastian Gardner, Sartre's Being and Nothingness: A Reader's Guide (London: Continuum, 2009).

Sebastian Gardner, 'The Transcendental Dimension of Sartre's Philosophy', in Jonathan Webber (ed.), Reading Sartre: On Phenomenology and Existentialism (London: Routledge, 2011), 48-72.

Jerome Gellman, 'Jean Paul Sartre: the Mystical Atheist', European Journal for Philosophy of Religion 1 (2009), 127-137.

John H. Gillespie, 'Sartre and God: A Spiritual Odyssey? Part 1', Sartre Studies International 19 (2013), 71-90.

John H. Gillespie, 'Sartre and God: A Spiritual Odyssey? Part 2', Sartre Studies International 20 (2014), $45-56$.

John H. Gillespie, 'Sartre and the Death of God', Sartre Studies International 22 (2016), 41-57.

Christina M. Gschwandtner, 'Turn to Excess: The Development of Phenomenology in Late TwentiethCentury French Thought', in Dan Zahavi (ed.), The Oxford Handbook of the History of Phenomenology (Oxford: Oxford University Press, 2018), 445-466.

David Bentley Hart, The Experience of God: Being, Consciousness, Bliss (New Haven, CT: Yale University Press, 2013).

G.W.F. Hegel, Science of Logic, trans. A.V. Miller (London: Allen \& Unwin, 1969).

Martin Heidegger, 'On the Essence of Ground', trans. William McNeill, in William McNeill (ed.), Pathmarks, (Cambridge: Cambridge University Press, 1998), 97-135.

Ludger Honnefelder, 'Metaphysics as a Discipline: From the "Transcendental Philosophy of the Ancients" to Kant's Notion of Transcendental Philosophy', trans. Jörn Müller and Russell Friedman, in Russel Friedman and Lauge Nielsen (eds.), The Medieval Heritage in Early Modern Metaphysics and Modal Theory 1400-1700 (Dordrecht: Kluwer, 2003), 53-74.

Christina Howells, 'Sartre and Negative Theology', The Modern Language Review 76 (1981), 549-555.

Christina Howells, Sartre: The Necessity of Freedom (Cambridge: Cambridge University Press, 1988).

Mark Jago, The Impossible: An Essay on Hyperintensionality (Oxford: Oxford University Press, 2014).

Dominique Janicaud et al., Phenomenology and the 'Theological Turn': The French Debate (New York: Fordham University Press, 2000).

Immanuel Kant, Critique of Pure Reason, trans. Norman Kemp Smith (London: Macmillan, 1929).

Thomas M. King, Sartre and the Sacred (Chicago: University of Chicago Press, 1974).

Kate Kirkpatrick, 'Jean-Paul Sartre: Mystical Atheist or Mystical Antipathist?', European Journal for Philosophy of Religion 5 (2013), 159-168.

Kate Kirkpatrick, Sartre on Sin: Between Being and Nothingness (Oxford: Oxford University Press, 2017).

Kate Kirkpatrick, Sartre and Theology (London: Bloomsbury, 2018).

Kris McDaniel, The Fragmentation of Being (Oxford: Oxford University Press, 2017). 
Katherine Morris, 'Sartre's Method: Philosophical Therapy or Transcendental Argument?', in Sorin Baiasu (ed.), Comparing Kant and Sartre (Basingstoke: Palgrave Macmillan, 2016), 197-216.

Iris Murdoch, Existentialists and Mystics (London: Penguin, 1999).

George Pattison and Kate Kirkpatrick, The Mystical Sources of Existentialist Thought: Being, Nothingness, Love (London: Routledge, 2018).

Sarah Richmond, 'Sartre and Bergson: A Disagreement about Nothingness', International Journal of Philosophical Studies 15 (2007), 77-95.

Sarah Richmond, 'Nothingness and Negation', in Steven Churchill and Jack Reynolds (eds.), Jean-Paul Sartre: Key Concepts (Durham: Acumen, 2013), 93-105.

Jean-Paul Sartre, L'Etre et le neant: Essai d'ontologie phénoménologique (Paris: Gallimard, 1943).

Jean-Paul Sartre, 'Materialism and Revolution', in Literary and Philosophical Essays, trans. Annette Michelson (New York: Collier Books, 1962), 198-256.

Jean-Paul Sartre, Words, trans. Irene Clephane (Harmondsworth: Penguin, 1967).

Jean-Paul Sartre, The Transcendence of the Ego, trans. Forrest Williams and Robert Kirkpatrick (New York: Octagon, 1972).

Jean-Paul Sartre, Existentialism and Humanism, trans. Philip Mairet (London: Methuen, 1973).

Jean-Paul Sartre, Mallarmé, or, The Poet of Nothingness, trans. Ernest Sturm (University Park, PA: Pennsylvania State University Press, 1988).

Jean-Paul Sartre, Notebooks for an Ethics, trans. David Pellauer (Chicago: University of Chicago Press, 1992).

Jean-Paul Sartre, Truth and Existence, trans. Adrian van den Hoven (Chicago: University of Chicago Press, 1995).

Jean-Paul Sartre, Being and Nothingness: An Essay On Phenomenological Ontology, trans. Hazel E. Barnes (London: Routledge, 2003).

Jean-Paul Sartre, 'A New Mystic', in Critical Essays, trans. Chris Turner (London: Seagull Books, 2010a), 219-293.

Jean-Paul Sartre, 'Cartesian Freedom', in Critical Essays, trans. Chris Turner (London: Seagull Books, 2010b), 498-532.

Jean-Paul Sartre, Being and Nothingness: An Essay In Phenomenological Ontology, trans. Sarah Richmond (London: Routledge, 2020).

Robert Stern, "Determination is Negation": The Adventures of a Doctrine from Spinoza to Hegel to the British Idealists', Hegel Bulletin 37 (2016), 29-52.

Josh Toth, 'A Différance of Nothing: Sartre, Derrida and the Problem of Negative Theology,' Sartre Studies International 13 (2007), 16-34.

Stephen Wang, Aquinas \& Sartre: On Freedom, Personal Identity, and the Possibility of Happiness (Washington, DC: Catholic University of America Press, 2009).

Jonathan Webber, 'Sartre's Transcendental Phenomenology', in Dan Zahavi (ed.), The Oxford Handbook of the History of Phenomenology (Oxford: Oxford University Press, 2018), 286-301.

Jonathan Webber, 'Sartre's Critique of Husserl', British Journal for the History of Philosophy 28 (2020), $155-176$. 